\title{
A MÚSICA ESPECTRAL E O RECIFE ASSOMBRADO: RELAÇÕES ENTRE A FICÇÃO, OS ITINERÁRIOS URBANOS E A PANDEMIA
}

André de Sena

Recebido em 23 out 2020. André de Sena é doutor, professor da Universidade Aprovado em 10 fev 2021. Federal de Pernambuco, idealizador e líder do Belvidera - Núcleo de Estudos Oitocentistas e pesquisador dos grupos de pesquisa Vertentes do Fantástico na Literatura e Núcleo de Estudos sobre Gêneros. http://lattes.cnpq.br/9977565773182194 https://orcid.org/0000-0003-2090-6398 andredesena.art@gmail.com

Resumo: O presente artigo, pelo viés da sociocrítica, busca analisar as relações entre a música e os sons incidentais nas produções literárias e cinematográficas do estado de Pernambuco de ontem e de hoje, bem como na imersão de um city-tour que possui elos com o gênero performance e dialoga com essas mesmas produções, abordando-se também a temática da pandemia e, especialmente, a realidade hodierna sob a Covid-19. Dessarte, o insólito e o horror são abordados sob duas perspectivas: num viés comparativista (ficção autoral literária e cinematográfica pernambucana, que também dialoga com obras artísticas do passado, em âmbito universal) e sociocrítico, a partir de leituras de cunho sociológico e da imersão artística na própria realidade possibilitada pelo city-tour $O$ Recife mal- 
assombrado. Nesta discussão, também se evidencia o signo da peste e da pandemia, outrossim, ditada por aportes insólitos/sobrenaturais.

Palavras-chave: Literatura e cinema de horror. Literatura e cinema pernambucanos. Literatura e sociedade. Covid-19.

Abstract: This article, from the perspective of sociocritics, seeks to analyze the relationship between music and incidental sounds in the literary and cinematographic productions of Pernambuco (yesterday and nowadays), as well as the immersion of a city-tour called Recife mal-assombrado, also addressing the theme of the pandemic and, especially, today's reality under Covid-19. In this way, the unusual and the horror are approached from two perspectives: in a comparative bias (authorial literary and cinematographic fiction from Pernambuco, which also dialogues with artistic works from the past, in a global perspective) and sociocritical, based on readings of a sociological perspective and immersion artistic in the Recife mal-assombrado city-tour. In this discussion, the sign of the plague and the pandemic is also evident, as well, inspired by the uncanny / supernatural.

Key-words: Horror literature and cinema. Pernambuco's literature and cinema. Literature and society. Covid-19.

Poder-se-ia afirmar que existiu, ou existe, um tipo de música ou de sons ligados ao sobrenatural? Se deixarmos conscientemente de lado a espiral de oblívio dos ritos autóctones, da multidão de eventos cultuais perdida na noite dos tempos, em que os instrumentos de percussão, sopros, cordas etc. tantas vezes mediaram os contatos entre os homens, os deuses e os mortos, e formos diretamente para o universo da arte propriamente dita, lograríamos de pronto falar: sim, "com efeitos"! 
Já nas tragédias gregas, por exemplo, o uso de ambientações musicais 'espectrais' estava garantido por uma ampla gama de instrumentos antigos, que incrementavam certas presenças fantasmáticas no palco, como ocorreria durante o aparecimento da sombra do rei Xerxes em Os persas (c. 472 a.C.), de Ésquilo, e diante da presença alusiva das erínias em Édipo em Colono (c. 401 a.C.), de Sófocles. Aliás, até mesmo o silêncio foi utilizado para se ressaltar a 'sobrenaturalidade' de determinados seres nos palcos antigos: as erínias, na peça esquiliana As eumênides (c. 458 a.C.), silenciam propositadamente em alguns momentos da ação dramática, no intuito de se gerar tensão e estranhamento precursores, entremesclados aos grunhidos desarticulados desses seres (que estão, por sinal, grafados no texto original). Da mesma forma, versos fragmentários de uma perdida tragédia esquiliana, Os edonos, revelam-nos outra experiência de sonoridades trágicas ligada aos fantasmas, quando se fala em "mugidos de touro" e no som de um tímpano que lembraria um "[...] trovão subterrâneo/ [que] se expande aterrador" (ÉSQUILO, 2008, p. 219). Segundo Dios (ÉSQUILO, 2008, p. 483), os tais mugidos de touro seriam criados por um aerofone livre capaz de gerar sons agudos e graves. Temos aí a matriz dos theremins utilizados nas décadas de 1960/70 em filmes de horror feitos por produtoras inglesas como a Hammer e a Compton Films.

Um dos maiores contistas do gênero horror de todos os tempos, o escritor norte-americano H. P. Lovecraft (1890-1937), em seu ensaio Horror sobrenatural em literatura (1927; 1939), também afirma a necessidade de algumas experiências sônicas para se gerar os efeitos góticos até mesmo nos textos escritos: 
Essa nova parafernália dramática [do romance gótico setecentista] consistia, antes de tudo, do castelo gótico com sua antiguidade espantosa, vastas distâncias e ramificações, alas desertas e arruinadas, corredores úmidos, catacumbas ocultas insalubres e uma galáxia de fantasmas e lendas apavorantes como núcleo de suspense e pavor demoníaco [...]; luzes estranhas, alçapões úmidos, lâmpadas apagadas, embolorados manuscritos ocultos, dobradiças rangentes, cortinados se mexendo, e tudo o mais. (LOVECRAFT, 2008, p. 28)

Quando fala especificamente sobre os romances góticos pioneiros de Ann Radcliffe (1764-1823), Lovecraft endossa o acima dito:

Alguns detalhes sinistros como um rastro de sangue na escadaria de um castelo, um grunhido numa galeria distante ou um som apavorante numa floresta noturna podem [...] conjurar as imagens mais poderosas de horror iminente. (2008, p. 30)

A música, ou um conjunto de sons (físicos: naturais, humanos; ou 'metafísicos': por exemplo, ruídos editados para se gerar estranhamento e sugerir o sobrenatural), sob as mais diversas formas de execução, gênero, substrato (instrumentos, montagem, edição, efeitos, mixagem, masterização etc.), ocupam lugar de destaque dentro desse aporte cronotópico que dá concretude à experienciação da topofobia e dos loci horrendi dentro da estética de horror, em fundamental consonância com o plano das imagens. Basta tapar os ouvidos, ou baixar o volume da tv ao assistir a qualquer película do gênero: metade - ou até mais, às vezes do efeito de suspense e medo se eclipsa automaticamente, por estar acusticamente moldado pelos diversos climas e paisagens sonoras, pelo jogo entre silêncios e aumentos súbitos de notas 
incidentais, monocórdicas ou não; ruídos aleatórios; nuvens de acordes abstratos; lancinantes notas agudas que sugerem novas fantasmagorias; um certo patético com o uso de theremins e sintetizadores Moog, entre outros.

Esse repertório de sonoridades e ruídos 'estranhos' que foram sendo associados à estética do horror ao longo dos séculos, dos primeiros monumentos artísticos, passando pelas obrasprimas românticas, pós-românticas etc., às obras comerciais que transbordam na cultura de massa de ontem e hoje, repercutiu também em âmbito popular, no imaginário coletivo, na 'linguagem das ruas', nas mais diversas sociedades e contextos. No caso brasileiro, que iremos explorar a partir de agora, são paradigmáticos os exemplos colhidos nas obras do sociólogo recifense Gilberto Freyre (1900-1987), especialmente Casa-grande e senzala (1933) e Assombrações do Recife velho (1955). No intuito de descerrar um provável ethos multicultural e multirracial nacional, a partir de vivências e experiências coloniais que ainda hoje repercutiriam na realidade urbana, Freyre não hesitou em buscar ao universo dos fantasmas e da fantasmagoria exemplos importantes para endossar seus argumentos. $E$, nesse contexto, não olvidou a importância dos fenômenos sônicos do ponto de vista de uma sociologia do sobrenatural, como a cognomina.

Já no clássico Casa-grande e senzala, o autor afirma a necessidade e importância desse olhar sociológico sobre as manifestações culturais ligadas ao sobrenatural. Numa passagem da obra, por exemplo, destaca alguns motivos que seriam comuns ao imaginário dos outrora florescentes engenhos de cana-deaçúcar do Nordeste brasileiro: 
[...] com cadeiras de balanço se balançando sozinhas sobre tijolos soltos que de manhã ninguém encontra; com barulho de pratos e copos batendo de noite nos aparadores; com almas de senhores de engenho aparecendo aos parentes ou mesmo estranhos pedindo padres-nossos, ave-marias, gemendo lamentações. (FREYRE, 2003, p. 20)

Os mal-assombrados das casas-grandes se manifestam por visagens e ruídos que são quase os mesmos por todo o Brasil. Pouco antes de desaparecer, estupidamente dinamitada, a casagrande de Megaípe, tive ocasião de recolher, entre os moradores dos arredores, histórias de assombrações ligadas ao velho solar do século XVII. Eram barulhos de louça que se ouviam na sala de jantar; risos alegres de dança na sala de visita; tilintar de espadas; ruge-ruge de sedas de mulher; luzes que se acendiam e se apagavam de repente por toda a casa; gemidos; rumor de correntes se arrastando; choro de menino; fantasmas do tipo cresce-míngua. Assombrações semelhantes me informaram no Rio de Janeiro e em São Paulo povoar os restos de casas-grandes do vale do Paraíba. (FREYRE, 2003, p. 20-21)

Mais de vinte anos depois, o escritor pernambucano não apenas continua a endossar esse mergulho acadêmico e sociológico no universo da cultura popular e imaginário sobrenatural, como escreve um livro específico que irá influenciar bastante o universo das artes em Pernambuco - especialmente a literatura, as artes plásticas e o cinema -, Assombrações do Recife velho. Por sinal, a obra recebeu primorosas ilustrações do artista plástico modernista Lula Cardoso Ayres (1919-1987), imagens espectrais associadas à cultura popular pernambucana, o que endossou ainda mais 
sua ligação com as artes. Nela encontramos outras interessantes passagens, como esta em que os fenômenos acústicos novamente aparecem como fundamentais à expressão do sobrenatural, no mito etiológico da praça recifense de nome Chora-menino:

Quando no silêncio das antigas noites recifenses se ouvia longe, por trás de velhos sobrados, um chôro mais triste de menino, era quase certo que a cabra cabriola estava devorando algum malcriado [...].

Às vezes, [...] era o chôro parecido com o de menino, mas de cururu ou de outro sapo tristonho, e com a fama de bicho de bruxo, em algum capinzal de beira de lagoa ou de rio, nas noites úmidas do Recife. Talvez tenha vindo daí o nome de Chora-menino que por tanto tempo foi o de um descampado da cidade, afinal chamado oficialmente por outro nome. (FREYRE, 1955, p. 12)

As casas recifenses tidas como mal-assombradas, tanto dos bairros burgueses como da periferia, também garantem toda uma acústica fantasmática, tartamudeada sob a forma de percussões e sopros, como no caso de um sobrado da rua de São José, uma das mais antigas da cidade:

Durante o dia assobios dentro da casa tôda. À noite, grandes baques, como de pianos de cauda virando de pernas para o ar, era um pagode: correntes arrastadas pelo soalho, as portas se abrindo, apesar de estarem fechadas com o ferrôlho e chave [...]. (FREYRE, 1955, p. 107)

Num dos muitos exemplos de confrontação explícita entre classes sociais distintas que aparecem no livro - em meio a manifestações do sobrenatural - Freyre fala sobre o caso do 
fantasma de um médico negro e uma "iaiá" racista e impiedosa que o maltratara quando ainda vivo:

Aliás, segundo a tradição popular, êsse doutor negro chegou a aparecer à cabeceira de mais de um doente pobre do Recife. Aparecia de cartola e de sobrecasaca como nos seus dias de homem da terra. Ou dêste mundo, como diria mestre Silva Melo, também médico e homem de ciência preocupado com o problema das assombrações.

De Dornellas se conta que, ainda vivo, passava certa vez, de sobrecasaca e de cartola, por uma das ruas mais fidalgas da cidade do Recife quando, da varanda de um sobrado opulento, iaiá mais aristocrática resolveu zombar de qualquer jeito do preto metido a sábio e encartolado como qualquer doutor branco. E não encontrou meio mais elegante de manifestar seu desdém pela "petulância do negro" que êste: cuspir-lhe sobre a cartola. Pois cartola era chapéu de branco e não de negro. Sentiu Dornellas a cusparada sobre o chapéu. E tirando a cartola ilustre e examinando a cusparada, diz a lenda que concluiu logo a ôlho nu: "Coitada da iaiá! Tuberculosa. Não tem um ano de vida". E antes de findar-se o ano, saía do sobrado fidalgo um caixão azul com o cadáver da moça. Morrera tuberculosa. (FREYRE, 1955, p. 49-50)

Os elementos ligados ao sobrenatural em Assombrações do Recife velho se conjugam ao estudo dos costumes, das vestimentas, da alimentação, dos ramos genealógicos, dos espaços urbanos (arquitetura e memória), da topografia, das doenças, das diferenças e confrontos de classe, e de inúmeras outras ramificações, num percurso histórico e sociológico que tem muito em comum com a École des Annales francesa e a história 
das mentalidades. Noutro prisma, é bem interessante como H. P. Lovecraft e Gilberto Freyre, dois autores de cultura e ideologia tão distintas, mesmo antitéticas, se encontram e repercutem nesses momentos em que buscam delinear a fenomenologia sobrenatural - o primeiro numa perspectiva ficcional, o segundo no ensaio sociológico que admite algo de ficção -, também no que toca ao plano das sugestões auditivas, corroborando com as tópicas dos malassombros.

Esse interesse pelo lado noturno, fantasmático, da cultura popular, Gilberto Freyre de certa forma herdou de um autor pernambucano de fins do século XIX, Carneiro Vilela (1846-1913). Em duas obras ficcionais, a novela $O$ esqueleto - crônica fantástica de Olinda $(1871 ; 1894)$ e o romance $A$ emparedada da rua Nova (1909; 1912), Vilela já havia trabalhado com determinados loci tidos como mal-assombrados no Recife, em sua cartografia de espantos e vozerios fantasmagóricos. Na primeira, encontramos as descrições dos cânticos, das percussões e dos horrores de eventos sobrenaturais que ocorreriam nas proximidades do marco náutico - provavelmente erigido durante o período de invasão holandesa em Pernambuco (c. 1630-1654) - em forma de cruz conhecido como Cruz do Patrão, num istmo que no século XIX ligava Recife a Olinda. No segundo, uma sugestão popular herdada, de sussurros e gritos noturnos das mulheres que eram emparedadas por pérfidos pais ou amantes, e depois se transformavam em aparições espectrais que atraíam incautos frequentadores das ruas centrais próximas ao cais, numa atmosfera de loucura. Vem dessas duas obras o processo inicial de transformação de determinados espaços urbanos recifenses 
em 'territórios de assombração', numa confusão até certo ponto conscientemente buscada entre ficção e realidade, ainda mais sedimentada e ampliada por Assombrações do Recife velho, de Gilberto Freyre, que em seu apelo memorialista ergue o pilar que faltava nesta construção de um 'Recife assombrado' e noturno, numa espécie de contraparte gótica a uma sua obra mais solar anteriormente publicada, o Guia prático, histórico e sentimental da cidade do Recife (1934).

Carneiro Vilela, com sua ficção de laivos sobrenaturais durante os estertores do romantismo e apogeu do cientificismo realista, e Gilberto Freyre, com sua visão exuberante sobre a cultura brasileira modalizada por uma hibridização entre pesquisa sociológica, verve literária, estudo folclórico e crônica jornalística, foram os responsáveis pelo surgimento de um imaginário que só se expandiria ao longo do século XX, a saber: a ideia de um Recife com suas ruas, sobrados, rios e descampados acossados por entidades sobrenaturais, num misto de nostalgia pelo passado e análise sociocultural do presente. Essa corrente dará lume a obras literárias que também participarão do mesmo modus operandi, a exemplo dos livros de contos 0 lobishomem da porteira velha (1956) e O cara de fogo (1969), de Jayme Griz (1900-1981), um autor da cidade de Palmares, que levou o imaginário de 'horror urbano recifense' para a Zona da Mata pernambucana, o som das correntes fantasmais agora a ecoar noite adentro nos velhos engenhos então abandonados, que deram lugar às usinas ao se demarcar um novo ciclo na produção capitalista da canade-açúcar. Inclusive, num dos contos de Griz, "As bexigas do engenho Bagaceira", de O lobishomem da porteira velha, o velho 
e abandonado engenho Bagaceira passa a funcionar novamente, com os ruídos de seus tachos, fornalhas e demais equipamentos voltando a ser ouvidos, movimentados por invisíveis mãos de fantasmas, para terror do protagonista da narrativa, que enlouquece ao tempo que ouve esses sons.

Muitos outros escritores e artistas, ao longo do século XX e, agora, do XXI, também quiseram transitar nessa via aberta pelas obras de Vilela, Freyre e Griz, de um 'horror folclórico-urbano recifense'. Focando apenas na produção mais recente, posso destacar os nomes de três contistas em plena atividade: Roberto Beltrão (1968-), autor de Na escuridão das brenhas (2013); André Balaio (1968-), autor de Quebranto (2018); e Frederico Toscano (1981-), autor de Carapaça escura (2019). Trabalhando contos que se passam no interior do estado e, principalmente, na zona urbana recifense, eles dão continuidade - cada um à sua maneira - a este interesse pelas assombrações da capital e de outras cidades, dentro de, aparentemente, novos contextos de crítica social, e um olhar atento aos estudos culturais na discussão latente - em meio ao horror e ao fantástico - sobre os direitos das minorias, os problemas sociais hodiernos e os confrontos de gênero e classe. Em outras palavras, a perspectiva sociológica, memorialista e folclórica de tempos passados ainda se presentifica na ficção imaginativa contemporânea recifense, que também não prescinde de um olhar atento sobre a realidade. Isso poderia, inclusive, sugerir a ideia de que a própria sociedade não haveria mudado tanto, do século XIX ao XXI, em termos de disparidades sociais, por exemplo, e a ficção fantástica ainda precisasse tocar nesse nervo para se autenticar de certa forma, revelando preocupação 
pelos problemas sociais, ou engajando-se. Em todo o caso, nos contos de Beltrão, Balaio e Toscano, o sobrenatural também se revela pelo sentido da audição, ora nas periferias recifenses, ora em meio ao tilintar de taças no apartamento burguês dos bairros de Casa Forte ou Boa Viagem; também nos rincões da cidade que mais se assemelham a espaços rurais, a revelar o atraso e a pobreza sempre presentes. Em cada um deles, um repertório sonoro próprio, ligado a diversas escolhas espácio-temporais atinentes a percepções de um sobrenatural que também evidencia o social, na crítica latente.

Algo muito parecido com o que ocorre na ficção literária se dá no universo cinematográfico local. Longas-metragens recentes como O som ao redor (2012) e Aquarius (2016), de Kléber Mendonça Filho (1968- ), e O Recife assombrado (2019), de Adriano Portela (1984-), partem, mutatis mutandis, dessa mesma premissa de que há uma tradição literária, folclórica e sociológica recifense secular, que não pode ser esquecida, mas ressignificada.

A estética de horror já havia sido trabalhada por Kléber Mendonça antes da realização de seus longas-metragens, nos curtas-metragens $A$ menina do algodão (2002) e Vinil verde (2004). E um tema recorrente em sua poética, o da destruição da memória, especialmente no descaso da especulação imobiliária pela arquitetura antiga do Recife - que, realmente, acaba por pôr tudo em ruínas -, aparece num de seus primeiros curtas, de inícios dos anos 90, com o título ambíguo, autoconscientemente, Paz a esta casa (1994).

A menina do algodão trata de um mito urbano, o fantasma de uma criança que se materializaria dentro dos banheiros causando 
pânico durante as madrugadas, também chamada "loira do banheiro", uma história que teve boa repercussão na cidade na década de 1990. Nele, a música é utilizada de maneira incidental, apenas no momento impactante de revelação sobrenatural, intermediada por longos silêncios onde apenas são percebidos os ruídos dos grilos que sugerem a madrugada e a região deserta da escola estadual onde se passa a história. Já em Vinil verde, a presença da música como motivo espectral se apresenta de forma mais contumaz, semelhante ao que ocorre, por exemplo, num conto específico de H. P. Lovecraft, "A música de Erich Zann" (1921), em que ela surge quase como uma personagem: no autor estadunidense, nos estranhos acordes de um violoncelista alemão cego; em Kléber Mendonça, na audição de um disco de vinil de cor verde. O curta, filmado num apartamento do bairro de Casa Amarela e adaptado de uma história do folclore russo, conta a história de uma mãe que dá de presente à sua filha uma coleção de discos coloridos, mas ordena que ela nunca ouça o de cor verde. Obviamente, a filha lhe desobedecerá, e a cada nova audição, uma parte do corpo de sua mãe desaparece. A rotina continua normal, mesmo com a mãe cada vez mais deformada, e nisso está o aspecto grotesco e até horripilante de Vinil verde, com algo de ironia macabra kafkiana. A trilha sonora é um misto de sons de pássaros, para marcar a atmosfera bucólica do bairro de Casa Amarela, chiados de vinil, silêncios de suspense que antecipam desfechos, e, nestes, notas repetidas que refletem a angústia e o sobrenatural, além das estranhas canções infantis que auguram tragédias, compostas pelo músico carpinense Silvério Pessoa, que tocam no pequeno vinil verde. 
Outro curta-metragem que antecede a produção dos longas de Mendonça e deve ser citado, não só pelo desenvolvimento técnico e de roteiro que o diretor alcança, mas por servir de elo perfeito entre os curtas iniciais e o que virá depois, é Recife frio (2009), o qual nos oferece uma interessante mistura de cinema fantástico, distopia sci-fi e comédia, cuja história assume ares de pseudopandemia no momento em que a cidade passa a ser atormentada por uma inversão térmica e se transforma num encrave quase polar, provavelmente devido à queda de um meteorito (um "acontecimento sobrenatural", segundo o texto, meio irônico, de divulgação do filme). No início da obra, que se nos é apresentada como um documentário realizado por um programa de tv hispânico, O mundo em movimento, são vistos homens, provavelmente uma polícia técnica ou cientistas, vestidos da mesma maneira como os profissionais que estão a desinfectar os lugares da Covid-19 neste exato momento, com roupas plásticas, luvas até os cotovelos, botas, máscaras e óculos protetores, isso tudo nas areias antes escaldantes da praia de Maria Farinha (1'22-1'46). Mesmo que a faceta principal do curta seja a cômica, há angustiantes imagens de cadáveres empilhados em sacos pretos, amontoados no "IML" - na realidade, os corredores da Fundaj e seu cinema de arte, onde Kléber trabalhou... -, os mortos pelo novo frio recifense na diegese (4'43-4'53), quase a prenunciar a tragédia da Covid-19 (o mais inquietante é que antes da primeira cena do filme, após os créditos de abertura, aparece uma frase que indica: "daqui a alguns anos..."). Mas uma antecipação efetiva de Recife frio se dá na crítica social afiadíssima, muito presente na obra filmográfica kleberiana posterior. Num dos vários casos que o documentário fictício 
apresenta como exemplos da "nova realidade" implementada pelo frio, há uma discussão em família, de classe média alta, sobre quem ficará com o quarto da área de serviço num apartamento de luxo de Boa Viagem. Chistosamente, o documentário explica a existência de tal cômodo - para o suposto público estrangeiro a quem é endereçado - como uma triste sobrevivência brasileira dos tempos coloniais e da escravidão, "fantasma moderno da senzala", como é dito, sem janelas para circulação de ar e situado no pior lado do prédio, onde o sol incidia antes com maior violência. Agora, por conta do frio, é o mais desejado, e acaba ficando com o filho mimado do casal dono do apartamento, enquanto a anterior moradora, a faz-tudo dos serviços domésticos, é transferida sem chance de discussão para sua anterior suíte com vista para o mar, que ninguém mais quer. E o comentário adicional da dona do apartamento, em entrevista à reportagem, revela uma ironia macabra nas relações interpessoais entre distintas classes sociais e a perversa inconsciência a esse respeito (um processo de naturalização das diferenças e silenciamento de direitos básicos dos desprivilegiados economicamente, até mais danosos); ela diz, literalmente: "Grace [o nome da funcionária] está passando frio e, de certa forma, se sentindo um peixe fora d'água, porque ela não é acostumada [...], nunca morou numa suíte" (MENDONÇA FILHO, 2009, 15'56-16'05). A inadequação ao frio de quatro graus que a funcionária tem de suportar é explicada como incapacidade 'natural' de adaptação a um cômodo maior e mais luxuoso. Também são relatados, e trabalhados com sutil ironia, em outros momentos do filme, o "medo paralisante da violência" (17'14); o "espaço urbano caótico, piorado por uma especulação imobiliária 
fora de controle" (17'27); a alienação e o consumismo desenfreados metaforizados pelos corredores dos shoppings lotados (semelhante ao que ocorre agora, em plena pandemia, em todo o Brasil), como efetivas antecipações aos longas-metragens $O$ som ao redor $\mathrm{e}$ Aquarius. Em outras palavras, as experiências do fantástico e do sci-fi continuam, como na literatura há pouco comentada, em plena sinergia com aquele olhar sociológico antes discutido; não à toa, o nome de Gilberto Freyre está nos agradecimentos dos créditos finais de Recife frio.

Por sua vez, O som ao redor e Aquarius também desenvolvem - com metáforas próprias e bastante criativas - uma temática já explorada na perspectiva sociológica de Gilberto Freyre, em seu livro Sobrados e mucambos (1936), que trata do poder ainda vivo do antigo patriarcado açucareiro, atualizado na figura dos poderosos donos de empresas da construção civil, os novos senhores de engenho dos séculos XX e XXI. Com um profundo senso estético ligado à expressão dos sons - a trilha sonora de $O$ som ao redor, por exemplo, se consolida com uma semiótica própria na construção de sentidos -, Kléber Mendonça Filho explora os medos, o caos social e os conflitos labirínticos da cidade grande e mal organizada, que parece querer mergulhar num suicídio vazio de memória, compondo também algumas cenas em que as sugestões sonoras estão ligadas a experiências sobrenaturais, de maneira geralmente sugestiva e subliminar, mas não menos poderosa (a exemplo do que faz Gilberto Freyre, inserindo índices fantasmáticos em sua discussão sociológica sobre a história e a economia coloniais). Em $O$ som ao redor, a silhueta de um menino negro aparece com ares de jump scare numa determinada cena, dentro de uma casa 
burguesa (também invadida por personagens 'subalternos' que na ausência dos donos vão em busca do intercurso amoroso), e ficamos até o fim em dúvida se se trata ou não de um fantasma, até ele ser capturado por dois seguranças de uma milícia que o agridem de maneira covarde, noutra passagem que antes também evocara fantasmagorias, com a estranha ascensão dessa criança numa árvore ${ }^{1}$. Noutra parte do mesmo filme, uma residência de classe média é invadida por uma multidão de crianças vestidas pobremente, mas essa cena revelar-se-á posteriormente como o pesadelo de outra criança, só que de classe mais privilegiada; em todo caso, num clima de completa fantasmagoria noturna. Já em Aquarius, há poderosas imagens que Kléber Mendonça constrói de uma espécie de invasão fantasmática do passado no presente, quando a protagonista Clara (Sônia Braga) parece, em meio a uma reunião familiar, pressentir a presença de uma antiga funcionária, já morta, que havia lhe furtado as joias da família. O episódio traduz em imagens toda a sutileza dos tratos interpessoais entre classes, mas é criativamente apresentado com algo da narrativa de horror.

Nesses dois longas-metragens, que conseguem metaforizar de maneira ímpar os terrores presentes nas pequenas desgraças do cotidiano de boa parte das classes média, média-alta e baixa

1 Gilberto Freyre, mais conciliador em relação aos fantasmas, numa história registrada por Roberto Beltrão (2007), costumava visitar um novo apêndice de sua casa, onde seu filho Fernando Freyre passou a habitar, para tentar ver a sombra de um menino que, dizia-se, ficava a brincar de quando em quando, correndo nas paredes dessa nova residência. Na realidade, todo o terreno onde se encontra a casa de Freyre, no bairro nobre de Apipucos - hoje, transformada em museu -, situa-se em terras de um antigo engenho; o surgimento da sombra da criança, segundo conversa de Beltrão com a esposa de Fernando Freyre, Maria Cristina Suassuna Freyre, dera-se concomitantemente à escavação de um terreno para a construção de uma piscina: foram descobertos artefatos e, a partir deles, soube-se que essa área era originalmente pertencente a uma senzala. Acreditou-se, na ocasião, que a construção da piscina sobre a área da antiga senzala poderia ter despertado a sombra dessa criança. 
recifenses, em suas relações diárias nos espaços internos das residências e nas ruas (um reflexo local do todo brasileiro), se prova que há fantasmas, e boa parte deles vem da própria realidade. Os fantasmas kleberianos são como os gilbertianos; também possuem um lastro mais balzaquiano e zoliano que lovecraftiano, ou seja, partem de uma circunstância real, de choques de classe; porém, mesmo assim, em certas passagens, graças a truques de edição e modalização narrativa, o sobrenatural e o horror não ficam de todo abandonados, existindo essa sugestão, corroborada também pelas escolhas estéticas anteriores de seus curtas.

Já O Recife assombrado, de Adriano Portela, é considerado por alguns como o primeiro - e tardio - longa-metragem do gênero horror produzido na cidade, e declaradamente inspirado em Assombrações do Recife velho, de Gilberto Freyre. Utilizando luz natural, o filme explora ruas e bairros já cartografados na obra freyriana, com um incremento extra de estranheza visual e auditiva. O som, tão importante no cinema, também revela todos os truques e recursos que já constituem tópicos, com as pausas ou silêncios alongados que antecedem massas de sonoridades aleatórias, ou notas recorrentes e monocórdicas a endossar a descoberta desconcertante do sobrenatural. Ou então, proporcionam o retardamento da ação, que gera o suspense característico. Elementos sonoros 'recifenses' também estão lá: nos sons dos vendedores de rua, no trânsito caótico dos horários de pico etc., tentando-se emular o real geralmente necessário para a irrupção de algum evento insólito. O filme de Portela pode ser compreendido dentro de uma macroestrutura que fomentou a redescoberta e várias releituras das obras de Gilberto Freyre desde fins da década 
de 1990, não apenas pela cultura letrada, mas também pela cultura do entretenimento, em especial nas adaptações de sua obra para o formato minissérie (na tv aberta) e para os quadrinhos; além das Comic cons, dos inúmeros fóruns, podcasts, comunidades na internet e páginas como $O$ Recife assombrado ${ }^{2}$, que buscam popularizar Freyre e chegaram mesmo a transformar algo de sua obra em cultura pop.

No gênero horror tradicional - ao qual o filme de Adriano Portela logo se associa - o real serve de antessala para o confronto com o sobrenatural, e geralmente aparece de forma convencional, por vezes estereotipada. No caso dos longas de Kléber Mendonça, o real está mais verticalizado psicologicamente, apresenta mais sutilezas, fissuras, espraiamento, sugestões, daí a presença de um sobrenatural mais elusivo. Mas paira sobre ambos os diretores - o primeiro mais ligado à cultura pop, o segundo ao cinema de arte - a mesma inolvidável sombra gilbertiana.

Muitos outros detalhes, não menos importantes, poderiam ser analisados dentro dessa produção cinematográfica recente; mas, em busca de uma imersão num panorama de 360 graus, e tendo em mente a discussão específica sobre as relações entre as sonoridades espectrais, os sons das ruas, e esta cultura recifense que consegue unir o olhar sociológico e o universo empírico às histórias de assombração (oralidade folclórica; ficcionalidade literária), gostaria de falar agora sobre uma proposta turística específica, que tentou trazer das páginas dos livros, dos traços dos quadrinhos e das imagens dos ecrãs esse mesmo imaginário, numa tentativa de experienciá-lo, ou mesmo concretizá-lo.

2 Disponível em: http://www.orecifeassombrado.com. 
Trata-se do passeio turístico Recife mal-assombrado, que é vendido em suas peças publicitárias como "O melhor city tour temático do país", e busca ir além do turismo literário tradicional - qualquer busca online irá, por exemplo, revelar dezenas de tours lovecraftianos em Providence, RI - ao propor recursos como a dramatização das obras de Gilberto Freyre e de outros autores aqui citados. Conversando com seu idealizador, das áreas de marketing e turismo, César Costa, fiquei sabendo de mais coisas sobre o projeto, que também intenta, segundo o mesmo, "valorizar a história e cultura da cidade; causar orgulho na ligação do morador com suas raízes; mostrar a cidade sob uma ótica diferente dos engessamentos turísticos e, claro, provocar reflexão sobre os dois planos que nos separam [o natural e o sobrenatural]" (COSTA, 2020).

A origem da "caminhada assombrada" vem de experiências colhidas na Europa, de acordo com César Costa:

Eu estava realizando uma produção para um documentário na Grã-Bretanha. Então conheci um trabalho semelhante em Edimburgo, Escócia. Só que esse tour leva você aos locais, conta suas histórias, mas não causa uma interação do público com o lugar. Tratava-se de tão somente uma comunicação de via única, onde o guia falava e o público só ouvia. No entanto, ele tinha o imenso apêlo de ser feito nos túneis que passam sob a cidade. Por si só, já é uma baita experiência. Passei a procurar por esse tipo de tour encontrando-o com mais entrosamento público/locais/história em Dublin, Irlanda. Lá o formato já se diferenciava, tendo alguns atores que encarnavam os seus personagens em pontos históricos assombrados da cidade. Com isso, logo pensei em trazer [a ideia] para Recife. Era o ano de 2015. Mas eis que 
aqui já havia um passeio, muito bem engendrado, promovido pela prefeitura sob o leque do projeto Olha Recife. Entrei em contato com a prefeitura, mostrei o projeto aos principais agentes envolvidos no turismo de Recife e Pernambuco e a aceitação foi imensa.

O primeiro tour foi realizado em julho de 2015 e, até antes da pandemia, o projeto recebera aproximadamente 9.000 espectadores. A faceta fantasmagórica da teatralização no início era "branda", mas o próprio público exigiu mais "adrenalina":

No começo entendíamos que uma liguagem mais branda, sem apelar para o estilo jump scare, seria o suficiente. Contudo, percebemos que o nosso público desejava algo mais experimental. Então lançamos mão de utilizar percepções sensoriais: cheiros, visões, sons. Contudo, sem nunca utilizarmos do expediente de correr atrás do público. Na verdade, nem é necessário. $\mathrm{O}$ mistério e o medo estão ali, à prova, na frente deles, causando susto só no fato de aparecer.

A influência da tradição de uma sociologia das assombrações recifense, como afirmado, também foi levada em conta, mas sem esquecer o cinema autoral de horror contemporâneo. Segundo César,

Apesar da exploração temática ser baseada no livro Assombrações do Recife velho, de Gilberto Freyre, fomos muito além disso. Utilizamos da linguagem de drama com suspense regional de Carneiro Vilela e as narrativas sombrias que vão evoluindo o suspense ao estilo de Edgar Allan Poe. Do cinema, as aparições e jogos de cena têm um misto de William Friedcker e M. Night Shayamalan, isso a depender do roteiro apresentado no dia. 
Há vários roteiros, todos explorando a um tempo aspectos históricos e ficcionais ligados às ruas recifenses, incluindo um roteiro específico associado aos "fantasmas" da Revolução, ou seja, aos mártires da Revolução Pernambucana de 1817, pioneira no processo de independência de Portugal e organizada pelos produtores de açúcar locais contra as taxas abusivas e os privilégios da aristocracia portuguesa vinda com a corte de $\mathrm{D}$. João VI para o país, em sua fuga dos exércitos napoleônicos. Os bairros escolhidos para a 'dramaturgia dos malassombros' estão na zona central e norte recifenses, mas há também andanças em Olinda e no Horto de Dois Irmãos.

Nas ruas centrais do bairro de São José, por exemplo, segundo César, a arquitetura já aparece como cenografia 'natural' para a experiência dramatúrgica dos fantasmas:

Com Friedkin, aprendemos a trazer o medo real. 0 medo do possível. Das coisas ou das situações do dia a dia. Todas as nossas histórias são baseadas em fatos reais ou, quando do imaginário popular, as que tenham fundo e origens. Com isso linkamos mais o público com a verdade estabelecida atrás de cada arquitetura dos prédios visitados, histórias e pensamento das gerações passadas. Então o medo com Friedkin é tangível. Já Shayamalan traz uma presença de cena que preenche todo o ambiente. Como no filme Os outros [2001], em que só os cenários quase monocromáticos já nos dão sensações de claustrofobia e desconforto. Procuramos sempre trazer uma lição reflexiva por trás de cada produção, como ele faz em seus filmes. Seja abordando as óticas de cada personagem, como também a autocrítica. Assim como ele tratou do isolacionismo em A vila [2004], 
a falta de convivência no aproveitamento da vida em $O$ sexto sentido [1999], e da autoridade familiar sobrepujadora em Os outros. Nada de Scary Movie apenas. A ambientação que fazemos se dá com a total ausência de luz, exceto a do guia e assessores com suas lanternas, espaços para exploração do público e que possuam histórias fortes, como é o caso de antigos casarões, museus, fortes, prédios, praças. Porém o forte [o mais intenso] está na narrativa dos guias, que, quase hipnoticamente, conseguem remeter o público à época em que se passa a história proposta, sintonizando-a com 0 lugar a ser visitado e os personagens que lá 'ainda' coabitam. Por isso são profundos conhecedores da história local e dos cernes culturais e espirituais que possam justificar o fenômeno.

Dessarte, o tour, segundo César, poderia ser compreendido não somente como uma performance teatral, mas uma experiência de imersão cultural, nessas trocas estabelecidas entre os lugares e as pessoas (as que participam das caminhadas e as da cidade em geral), a memória desses mesmos lugares, e as (re)leituras que os atores fazem das obras literárias:

Sem dúvida é um completo e total mergulho cultural. A performance teatral é a chave nessa ligação. São histórias encenadas de dramas, sofrimentos, maldições etc. Para 90\% [do público participante], aqueles lugares eram só para passagem, mas ao se depararem com os motivos, inspirações e modelagens de seus artistas criadores, há um balanço do seu modo de pensar a cidade. É esse nosso objetivo maior. Causar uma colisão entre o morador, sua cidade, sua história e sua arte.

Em relação aos fenômenos sônicos, aos ruídos das ruas durante as encenações do tour, se há a presença da música e/ou de efeitos 
para se gerar as sugestões sobrenaturais, e se os silêncios também são explorados, diz-nos César:

Usamos som gravado somente em cerca de $20 \%$ de todo o nosso percurso. Porém nenhuma fala é gravada, mas tão somente sons ambientes. O silêncio e o som urbano são nossos aliados no processo. Quando das nossas apresentações há um trabalho de redução de percepção externa, focando nos sentidos e aguçando-os somente para o que está em volta, a pouco metros. Isto é natural em momentos de estresse e medo. Então o foco do público mira nos passos, no estalar das portas e maçanetas, em sons de sussurros, batidas no ambiente visitado. Nossas visitações externas abrangem somente locais de pouca movimentação. Evitamos grandes aglomerados. Recife tem a característica de estar mais muda a partir de certas horas nessas locações. Quando há algum advento que desconcentra o público, retrabalhamos a sintonia e concentração dele.

De outro lado, a própria cidade por vezes parece responder e interagir com o tour, também participando de alguma forma. De acordo com seu organizador,

Toda cidade é um imenso teatro. Exemplo clássico é quando apresentamos a [obra] $A$ emparedada da rua Nova [,] [de Carneiro Vilela]. Nas primeiras apresentações, temíamos a reação dos passantes e dos que ficam naquela rua até bem mais tarde. Com o passar do tempo vimos que eles já começavam a nos esperar com cadeiras e bancos já nas marcações. Quando alguém externo fazia alguma piada ou barulho, estes que já estavam lá reclamavam com energia contra o perturbador que, invariavelmente, se calava de imediato. A reação de passantes não acostumados acaba 
fazendo parte do show com seus medos e reações. Já houve quem desequilibrou-se da bicicleta ao avistar 'assombrações'; vendedor que abandonou seu carro de pipoca e saiu correndo ao ver a Emparedada saindo de um beco escuro em meio a uma cortina de fumaça; pessoas que retornam correndo ao deparar-se com alguma das assombrações [os atores] na rua. Uma das passagens mais engraçadas foi a de um bebum que correu atrás de agarrar a assombração mandando o público se proteger enquanto ele se sacrificava: "Fujam que eu seguro ele. Se salvem", gritava ele. Desmaiando de medo nunca teve, mas tivemos uma senhora que começou a correr desembestada ao bater de frente com a Loira do Banheiro. O nosso segurança foi quem a segurou, acalmando-a. Ela nos explicou que era uma lembrança da infância dela.

Nessa troca de sussurros, olhares, sustos e memórias, em que o tour parece reafirmar aquele mesmo princípio antes debatido em relação à literatura e ao cinema pernambucanos a confluência entre a ficcionalidade, o imaginário da estética de horror e o universo empírico -, por vezes até mesmo experiências aparentemente sobrenaturais ocorreriam nele:

Uma senhora que preferiu ficar do lado de fora da locação para atender uma ligação junto ao segurança do prédio, resolveu entrar depois. Nisso ela foi guiada por uma criança até o local onde estávamos no andar superior, na parte de trás do palacete, em corredores complicados de se andar, principalmente às escuras e sem conhecimento, só com a luz da tela do celular. Ao encontrar o grupo e o guia, explicou como o achara. Entretanto não havia nenhuma criança no local. Nem com os únicos funcionários (o gestor e dois seguranças 
do prédio), nem com a nossa equipe técnica. Intrigados, resolvemos recapitular e constatamos que nenhum dos seguranças havia levado alguém e que o gestor foi trazido e levado de volta por nossa equipe sem a companhia de qualquer criança. Foi quando ele nos explicou que não era a primeira vez que tinham falado daquele menino ali. E que já houve segurança que implorou troca de turno ao começar a vê-lo. Claro que nosso público adorou a experiência. De outra oportunidade, estávamos na Praça Chora Menino contando a história do local e de algumas casas. Ao final das explicações algumas pessoas do grupo vieram nos perguntar quem era o ator que estava no andar superior de uma das casas. $\mathrm{O}$ guia explicou que não era ator e que era quase impossível haver, pois as portas e janelas dela estavam lacradas com tijolos para impedir invasões, já que estava abandonada. Constatamos depois que a casa continuava lacrada, restando somente algumas janelas superiores para as quais não havia acesso externo. Isso causou uma enorme euforia, já que pessoas que não se conheciam relataram a [mesma] visão.

Vê-se aí aquele mesmo frisson pelo sobrenatural, que fazia com que Gilberto Freyre fosse à casa vizinha de seu filho para tentar ver a sombra de um menino correndo nas paredes; e relatasse uma visita que fizera a um poço considerado malassombrado, juntamente a outro estudioso, em passagem de Assombrações do Recife velho.

Da mesma forma como encontramos algum prazer e catarse em assistir a uma película de horror no conforto de um cinema (ou em casa, durante a pandemia), o ato de andar em grupo à noite, com seguranças, pelas ruas centrais de uma cidade hoje também 
conhecida pela violência, durante o tour Recife mal-assombrado, acaba gerando um outro tipo de experiência principalmente para as novas gerações, uma espécie de 'horror controlado': "Vale a pena registrar que a cidade permite uma outra visão sobre ela à noite. Em grupo, as pessoas se sentem à vontade para ver detalhes como as fachadas de sobrados, arquiteturas de igrejas, detalhes dos casarões", afirma César Costa.

Mas ao terror real da violência, um outro se juntou - tão ou mais angustiante, por sua invisibilidade fantasmagórica -, o da Covid-19. O tour encontra-se parado desde o dia 13 de março, quando ocorreu o último passeio antes da pandemia, simbolicamente uma sexta-feira 13. "Como se trata de evento cultural, só será liberado na fase 9 [instituída pelo Governo do estado], que ainda não tem previsão de acontecer, segundo as autoridades", diz o empresário, que também fala sobre uma "demanda reprimida" neste momento:

Durante esse tempo [de paralisação] notamos que há um público ávido por fazer os passeios, então há uma demanda reprimida, o que mostra que o receio do recifense não está focado propriamente no vírus, mas sim no fato de estar parado. Para saber o impacto que essa pausa causou em nosso público, teremos que sondar durante os primeiros passeios assim que voltarmos à normalidade. Algumas pessoas poderão trazer traumas referentes à morte de parentes ou de amigos, mas todos aqueles que vêm para o Recife mal-assombrado já trazem a ideia de que terão que lidar com histórias sobre a morte, antes mesmo de fazer sua inscrição no passeio. Em geral, a faixa etária de nosso grupo está entre 35 e 65 anos; são maduros, de boa instrução, e têm 
uma diferente ideia de percepção e realidade sobre o fator morte.

Em todo o caso, neste momento (setembro de 2020) em que o Brasil já chega a quase 130 mil mortos oficiais pela Covid-19, contraditoriamente as ruas se enchem cada vez mais, e no mais recente feriado (7 de setembro), os jornais e tvs alardearam as praias lotadas e o absurso no desleixo das pessoas para com a pandemia. Mas - para finalizar - o curioso é que, mesmo neste contexto pandêmico, os fantasmas urbanos continuam com seu apelo no imaginário recifense. Um vídeo que circulou bastante nas redes sociais - e ainda repercute (ou seja, "viralizou", como se diz hoje) - a ponto de chamar a atenção da mídia e gerar reportagens jornalísticas (lembrando que Assombrações do Recife velho, de Freyre, teve como fonte inicial os vários 'fatos sobrenaturais' noticiados pela imprensa do período), mostra a silhueta de uma menina que, durante as madrugadas (sempre entre às duas e três horas), do oitavo andar de um apartamento localizado no bairro central de Boa Vista, se balança perigosamente numa rede, aparentemente sozinha. O vídeo foi filmado por moradores de um prédio em frente ao local, preocupados porque na varanda não havia tela de proteção, e em seu balançar a provável criança parece ultrapassar a beirada. Segundo a reportagem, os responsáveis pela filmagem informaram ao vigia do prédio sobre a situação, mas ele teria dito que naquele apartamento só moraria um casal de idosos, mas nenhuma criança. O vídeo se espraiou em todo o país, com dezenas de milhares de visualizações. Até o momento não se chegou a uma conclusão sobre ele, e as lendas urbanas vão se avolumando, bem como tentativas de explicação de todos os 
matizes. Se augura um novo fantasma recifense: a menina da rede. Só que - alguns hão de lembrar -, em 1955, Gilberto Freyre já falava sobre os sons fantasmagóricos que até das redes poderiam surgir ("redes fantasmas"):

Não é de estranhar que moradores de uma rua de São José acreditem ser assombração um ranger de escada burguesa. Mais de uma casa da região tem ganho fama de assombrada por causa de algum ranger misterioso: de escada, de punho de rêde, de cadeira de balanço. Na casa-grande de velho engenho do Sul de Pernambuco é tradição que range, no silêncio das meias-noites, antiga cadeira de balanço em que se balançava certa iaiá ninando o filho. Em casagrande de engenho também antigo das Alagoas, na sala em que aconteceu há quase um século um crime terrível, contou-me uma vez - General Pedro Aurélio de Góis Monteiro que é tradição ranger misteriosamente, no silêncio da noite, o punho da rêde. Mais de uma vez pessoas calmas, e de modo algum arrebatadas ou crédulas, têm se levantado para verificar quem está se balançando na rêde. Não encontram ninguém: nem mesmo rêde. $O$ ranger de punho de uma rêde que não mais existe continua um mistério. (FREYRE, 1955, p. 57)

E com a imagem desse utensílio tão tipicamente brasileiro - a rede, de origem ameríndia, que durante o Brasil Colônia foi adaptado ao cotidiano dos brancos europeus e dos nascidos brasileiros, seja para o transporte, o descanso, ou mesmo para se enterrar os mortos -, aqui fantasmagorizada e espraiada pela nova rede (a Web), termino este périplo pelos sons e assombrações recifenses redivivos. 


\section{REFERÊNCIAS}

A MENINA do algodão. Direção de Kléber Mendonça Filho. Recife: CinemaScópio Produções, 2003.

AQUARIUS. Direção de Kléber Mendonça Filho. Recife: CinemaScópio Produções; SBS Productions; Videofilmes; Globo Filmes, 2016.

BALAIO, André. Quebranto. São Paulo: Patuá, 2018.

BELTRÃO, Roberto. Na escuridão das brenhas. Recife: Bagaço, 2013.

BELTRÃO, Roberto. Estranhos mistérios d'O Recife assombrado. Recife: Bagaço, 2007. ÉSQUILO, SÓFOCLES, EURÍPIDES. Obras completas. Madrid: Ediciones Cátedra, 2004. ÉSQUILO. Fragmentos, testimonios. Madrid: Gredos, 2008.

FREYRE, Gilberto. Casa-grande e senzala: formação da família brasileira sob o regime da economia patriarcal. 48. ed. São Paulo: Global, 2003.

FREYRE, Gilberto. Assombrações do Recife velho. Rio de Janeiro: Condé, 1955.

LOVECRAFT. H. P. O horror sobrenatural em literatura. São Paulo: Iluminuras, 2008. O SOM ao redor. Direção de Kléber Mendonça Filho. Recife: CinemaScópio Produções, 2012.

PAZ a esta casa. Direção de Kléber Mendonça Filho. Recife: CinemaScópio Produções, 1994.PORTELA, Adriano. O Recife assombrado. Recife: ViuCine, 2019. RECIFE frio. Direção de Kléber Mendonça Filho. Recife: CinemaScópio Produções, 2009.

Recife mal-assombrado city tour. In: www.recifemalassombrado.com.br.

TOSCANO, Frederico. Carapaça escura. São Paulo: Patuá, 2019.

Vídeo da menina fantasma. Disponível em: https://www.orecifeassombrado. com/a-menina-da-rede-assombrada/. Acesso em 2 set. 2020.

VINIL verde. Direção de Kléber Mendonça Filho. Recife: CinemaScópio Produções, 2004. 